\title{
A Study on the Hydrolysis of Urea Contained in Wastewater and Continuous Recovery of Ammonia by an Enzymatic Membrane Reactor
}

\author{
Mukhtar Nuhu Yahya ${ }^{1, *}$, Hüseyin Gökçekuş ${ }^{1}$, Derin Orhon ${ }^{1,2}$, Bülent Keskinler ${ }^{3}$, Ahmet Karagunduz ${ }^{3}$ \\ and Philip Isaac Omwene ${ }^{3,4}$
}

1 Department of Civil Engineering, Faculty of Civil and Environmental Engineering Near East University, TRNC, Mersin 10, Nicosia 99138, Turkey; huseyin.gokcekus@neu.edu.tr (H.G.); orhon@itu.edu.tr (D.O.)

2 ENVIS Energy and Environmental Systems Research and Development Ltd., ITU ARI Technocity, Maslak, Istanbul 34469, Turkey

3 Faculty of Environmental Engineering, Gebze Technical University, Cumhuriyet, 2254. Sk. No:2, Gebze, Kocaeli 41400, Turkey; bkeskinler@gtu.edu.tr (B.K.); akaragunduz@gtu.edu.tr (A.K.); piomwene@gmail.com (P.I.O.)

4 Faculty of Agriculture and Environmental Sciences, Muni University, Arua P.O. Box 725, Uganda

* Correspondence: mnyahya.age@buk.edu.ng; Tel.: +90-533-521-890

check for updates

Citation: Yahya, M.N.; Gökçekuş, H.; Orhon, D.; Keskinler, B.; Karagunduz, A.; Omwene, P.I. A Study on the Hydrolysis of Urea Contained in Wastewater and Continuous Recovery of Ammonia by an Enzymatic Membrane Reactor. Processes 2021, 9, 1703. https://doi.org/10.3390/pr9101703

Academic Editors: Alexandros Stefanakis, Yaqian Zhao,

Arlindo Gomes, Simos Malamis and Hah Young Yoo

Received: 21 April 2021

Accepted: 16 June 2021

Published: 23 September 2021

Publisher's Note: MDPI stays neutral with regard to jurisdictional claims in published maps and institutional affiliations.

Copyright: (c) 2021 by the authors. Licensee MDPI, Basel, Switzerland. This article is an open access article distributed under the terms and conditions of the Creative Commons Attribution (CC BY) license (https:// creativecommons.org/licenses/by/ $4.0 /)$.
Abstract: 1. Background: Urea is the main product of the nitrogenous breakdown of protein metabolism in mammals. In this study, process intensification for enzymatic hydrolysis of urea by urease enzyme (jack bean urease) was examined in a membrane reactor. 2. Methods: Batch and continuous enzymatic hydrolysis reactions were performed at different substrate concentrations to determine the digestibility and affinity of the substrate with that of the enzyme. The hydrolysate samples were obtained by an optimized continuous enzyme membrane reactor (EMR) coupled with an ultra-filtration membrane $(250 \mathrm{kDa})$. Feed concentration varied from 100 to $500 \mathrm{mg} / \mathrm{L}$. Laboratory experiments were conducted at room temperature $\left(20 \pm 1^{\circ} \mathrm{C}\right)$, with a flow rate of $20 \mathrm{~mL} / \mathrm{min}$, urease concentration of $0.067 \mathrm{~g} / \mathrm{L}$, ionic strength $(I=0,0.01,0.05)$, and ammonium nitrogen addition of $(0,100 \mathrm{mg} / \mathrm{L}, 200 \mathrm{mg} / \mathrm{L}, 500 \mathrm{mg} / \mathrm{L})$. Moreover, the effect of ionic strength, ammonium nitrogen concentration, feed concentration, and enzyme concentration on urea hydrolysis was examined. Scanning electron microscopy (SEM) and energy dispersive X-ray spectroscopy (EDAX) analysis were used to identify the physicochemical properties as well as the elemental composition of the Ultra-Filtration membrane used in this study. 3. Results: The study revealed that higher ionic strength and higher concentrations of $\mathrm{NH}_{4} \mathrm{SO}_{2}$ and ammonium nitrogen $\left(\mathrm{NH}_{3}-\mathrm{N}\right)$ inhibithydrolysis of urea by reducing the urease enzyme activity in the system over time. 4. Conclusions: Herein, a sustainable alternative for the conversion of urea to ammonia by utilizing urease in an EMR was demonstrated.

Keywords: urea; urease; hydrolysis of urea; ultra-filtration; continuous reactor; scanning electron microscopy

\section{Introduction}

Pure urea is a colorless, odorless solid that has a weak base but is stronger than most amides and can be hydrolyzed in the presence of acids, bases, and urease [1]. Urea in an aqueous solution with ammonium nitrate or magnesium sulphatethat can be applied to agricultural lands as foliar fertilizer. Urea not only enters the environment via the washing of fertilizers from agricultural lands and wastewater from urea production plants, but also by leaching from fields and agro-breeding farms, in effluents from plants using urea as raw materials, and from the final product of mammalian protein metabolism. Protein metabolism is the reason behind the abundance of urea in coastal systems. Due to the extensive use of urea by many industrial sectors, it is produced in large volumes in their waste $[1,2]$. 
Industrial and domestic wastewaters contain significant volumes of nitrogenous compounds, urea and ammonia inclusive. Urea is a major nitrogenous fertilizer used in agriculture. Annually, 100 million tons of urea are produced, of which abundant quantities are used as mineral fertilizer [3]. Considerable quantities of both urea and ammonia find their way into wastewater, mainly through runoffs that cause more harm than good to the environment and discharge large volumes of pollutants to receiving water bodies. This discharged wastewater from the production plants can have an $\mathrm{NH}_{3}-\mathrm{N}$ level of approximately $125 \mathrm{mg} / \mathrm{L}$ and a urea level of approximately $750 \mathrm{mg} / \mathrm{L}$. Approximately $40-50 \%$ of the total nitrogen in municipal wastewater treatment plants is in the form of ammonium ions $\left(\mathrm{NH}_{4}{ }^{+}\right)$[4]. Ammonia is a toxic pollutant in wastewaters that both affects fish species and is undesirable for humans as it is oxidized by nitrifying microorganisms to form nitrite and nitrate [5]. Ammonia reacts with carbon dioxide at high temperatures and pressures industrially to form what is called urea.

Urea demand has increased significantly with the rapid development of chemical industries and population growth as food security is needed by all countries. Urea is not only an important nitrogen fertilizer per se, but is also a good raw material for chemical producing industries. Around $85 \%$ of the total ammonia production in the world is consumed as fertilizer, with the remaining $15 \%$ used in other industrial applications such as fibers, plastics, and explosives among others [6]. Currently, there is worldwide attention on achieving food security, which has made urea and other forms of agricultural fertilizers increasingly scarce [2].

Excessive plant growth in the ecosystem is generally caused by the overload of the two most harmful environmental problems' common species, which are ammonia and ammonium $\mathrm{NH}_{3} / \mathrm{NH}_{4}$. These two generate the well-known eutrophication phenomenon and reduce water quality. Ammonia is a harmful air pollutant because of its adverse impact on human health as well as climate change. In this sense, ammonia production is considered as an industrial source of carbon dioxide emissions causing the greenhouse effect [6]. Apart from human activities, other large amounts of waste waters containing urea are generated from urea production processes. Moreover, coastal systems have been facing tremendous attacks from urea as a result of the anthropogenic activities of many industries in recent decades, which has attracted the attention of numerous researchers in order to devise a solution to this problem [2].

Several chemical processes exist for manufacturing ammonia. The three most wellknown and widely used methods are the Haber-Bosch process, indirect electrochemical process, and urea decomposition. The Haber-Bosch process was developed a century ago and is implemented at a very high temperature of between 400 and $500{ }^{\circ} \mathrm{C}$ and a pressure of between 130 and 170 bar. In this process, gaseous hydrogen and nitrogen react over a metal catalyst at a high temperature and pressure [7]. This process is very costly as it requires higher temperatures and pressures. Secondly, an electrochemical process is also used for removing ammonia and other pollutants from wastewater. It is a reliable process for treating wastewater with the advantages of minimal sludge generation, high operating efficiency, and the ability to operate under a wide range of ambient temperatures. The limitations of this process include: chlorine ion concentration in wastewater, $\mathrm{pH}$, current density, the electric voltage applied, and the type of anode used. Higher current densities also affect this system, as this leads to more electric power consumption and directly increases the operational cost [8]. Another process used in ammonia removal/recovery is urea decomposition by either catalytic, strong oxidant, or hydrolysis processes. All these processes listed above have their respective limitations and costs as all are conducted at high temperatures and pressures, which limits their usage by many industries [1].

Many methods can be used in urea recovery or removal, and more are either at the development level or are being newly introduced. These include: hydrolysis of urea, enzymatic hydrolysis, catalytic decomposition of urea, decomposition by strong oxidants, removal by adsorbents, electrochemical urea removal method, etc. [1,9]. Moreover, several ongoing researches are being funded by many industries on urea recovery and conversion 
to ammonia. Urea discharge is becoming a challenge for many industries because of environmental laws and regulations. This research aims to propose an alternative separation technique for the recovery of ammonia from urea, and if this ammonia is recovered, it can be used in ammonia-based fertilizers by farmers and can contribute to lowering the cost of wastewater treatment and environmental sustainability [10].

In this study, urea hydrolysis was analyzed in synthetic wastewater prepared in a laboratory. We also investigated the dependence of the enzyme (urease) on ionic strength, ammonium nitrogen addition and on different feed concentrations, as well as how all these features affect the hydrodynamic, design, and performance of the system. An effective enzyme membrane reactor (EMR) system was set up for the recovery of ammonia that will convert the problematic pollutant urea that is mostly found in industrial as well as agricultural runoffs into an attractive economical commodity.

Moreover, with the prospect of achieving the complete recovery of urea in wastewater by an enzymatic process, this work presents an interesting example of coupling a chemical/biological reaction and a membrane separation technology. In addition, integrating membrane technology with biological processes will also help in enhancing organic removal and thereby reducing the fouling effects in the membrane [11]. This system is proposed because of its uniqueness in terms of enriching the ammonium ion inside the reactor and separating it from foreign matter with less energy input. Moreover, the system will also have an advantage over the previous enzymatic systems in terms of conversion, enzyme stability, and efficiency [12]. The retention of enzymes in the system will make the slurry recycling economically sound and enhance the cleaning of the membrane. When implemented, the system will have the unique advantage of enzyme recovery, which is lacking in other conventional batch reactors. The membrane system will also help in the separation or selectivity of components in the reactor according to their molecular weights. Furthermore, the results of this research will be useful for any wastewater containing urea.

\section{Materials and Methods}

\subsection{Batch Hydrolysis}

Batch enzymatic hydrolysis reactions were performed at different substrate concentrations in order to determine the digestibility and affinity of the substrate with that of the enzyme. Consequently, rate model parameters were determined to provide a basis for comparison between the batch and the continuous-mode enzymatic hydrolysis. A batch system was used to establish the kinetic parameters $\left(V_{\max }\right.$ and $\left.K_{m}\right)$, which are essential in analyzing substrate-enzyme interactions. The continuous operation will serve as a proofof-concept for the development of an EMR system to be used in the conversion of urea to ammonia in wastewater treatment systems. The system will consist of a reactor coupled with an Ultra-Filtration membrane. In the batch experiments, 100, 200, 500, 1000, 2000, and $4000 \mathrm{mg} / \mathrm{L}$ urea-N were mixed with different concentrations of urease enzyme in a batch reactor. Urease concentrations of $0.20,0.15,0.10$, and $0.067 \mathrm{~g} / \mathrm{L}$ were studied to measure the activity of the urease at different concentrations and the time taken for the hydrolysis was measured and recorded. Furthermore, $0.067 \mathrm{~g} / \mathrm{L}$ of enzyme (urease) was used in order to minimize the use of urease in the system as it is expensive. Moreover, higher enzymatic concentrations in membrane processes increase membrane fouling. Membrane fouling and enzyme activity decay are the two most significant limitations that affect the performance of an EMR. All this was done at room temperature and an effluent $\mathrm{pH}$ of between 7.0 and 7.5 .

\subsection{Materials Used}

The urea used for this research was purchased from Merck KGaA,64271 (Darmstadt, Germany) with the following physicochemical properties: purity of $99.5 \%$; $\mathrm{pH}$ value of 9.0; molar mass of $60.06 \mathrm{~g} / \mathrm{mol}$; density $1.34 \mathrm{~g} / \mathrm{cm}^{3}$; and melting point of $132-134{ }^{\circ} \mathrm{C}$. Furthermore, $100 \mathrm{mg} / \mathrm{L}$ and $500 \mathrm{mg} / \mathrm{L}$ of substrate concentration were used for all the analyses at a room temperature of $20 \pm 1^{\circ} \mathrm{C}$ and a fixed enzyme concentration of $0.067 \mathrm{~g} / \mathrm{L}$. Urease 
enzyme (EC.3.5.1.5 Lyophilized) was purchased from Merck (KGaA 64271, Darmstadt, Germany). The enzyme has a specific activity at $5 \mathrm{U} / \mathrm{mg}$. After the enzyme solution was prepared, it was stored in a refrigerator at $-5{ }^{\circ} \mathrm{C}$ for further use [13]. Deionized water used for the experiments was produced by the MilliQ SP ultra-pure-water purification system (Nilcon Millipore Ltd., Tokyo, Japan). All other chemicals were extra pure or guaranteed commercially available reagent.

\subsection{Enzyme Hydrolysis Reaction}

The standard method for determining the kinetic parameter involves running a series of enzyme assays at multiple substrate (urea) concentrations and measuring the initial rate of reactions. For this study, different substrate (urea) concentrations were used starting from $200 \mathrm{mg} / \mathrm{L}, 500 \mathrm{mg} / \mathrm{L}, 1000 \mathrm{mg} / \mathrm{L}, 2000 \mathrm{mg} / \mathrm{L}$, and $4000 \mathrm{mg} / \mathrm{L}$ in order to determine the enzyme kinetic parameters $\left(\mathrm{K}_{\mathrm{m}}\right.$ and $\left.\mathrm{V}_{\max }\right)$ at $\mathrm{pH}$ variation from $\mathrm{pH} 4$ to 10 , and an enzyme (urease) concentration of $0.067 \mathrm{~g} / \mathrm{L}$.

After the hydrolysis was started, the reaction was ceased after $5 \mathrm{~min}$ via the addition of concentrated hydrochloric acid $(\mathrm{HCl})$. All the collected samples were tested for ammoniumnitrogen in a Kjeldahl's distillation machine as guided by the standards.

\subsection{Continuous Enzymatic Hydrolysis of Urea}

Continuous studies were carried out in a 4 L Bioreactor (BIOFLO 3000) coupled with an ultra-filtration membrane and stirred at $200 \mathrm{rpm}$. Two high pressure automated peristaltic pumps (Watson Marlow Peristaltic Pump Hydra cell, Falmouth, Cornwall, United Kingdom) equipped with a flow regulator were used to maintain the water in the reactor (Figure 1). The UF membrane used in this study was purchased from Sterlitech (Auburn, WA 98001, USA). The active layer of the UF membrane is made of polyvinylidene fluoride (PVDF) with a250 KDa molecular weight cut-off (MWCO). The UF membrane was expected to prevent the urease from passing to the permeate side of the membrane. Backwashing of the membrane was done with deionized water for $1 \mathrm{~h}$ after each experimental run, in order to keep the membrane clean and reduce fouling. To further reduce risks associated with contamination and mixing, all equipment used was thoroughly cleaned before usage and the reactor vessel was washed and sterilized.

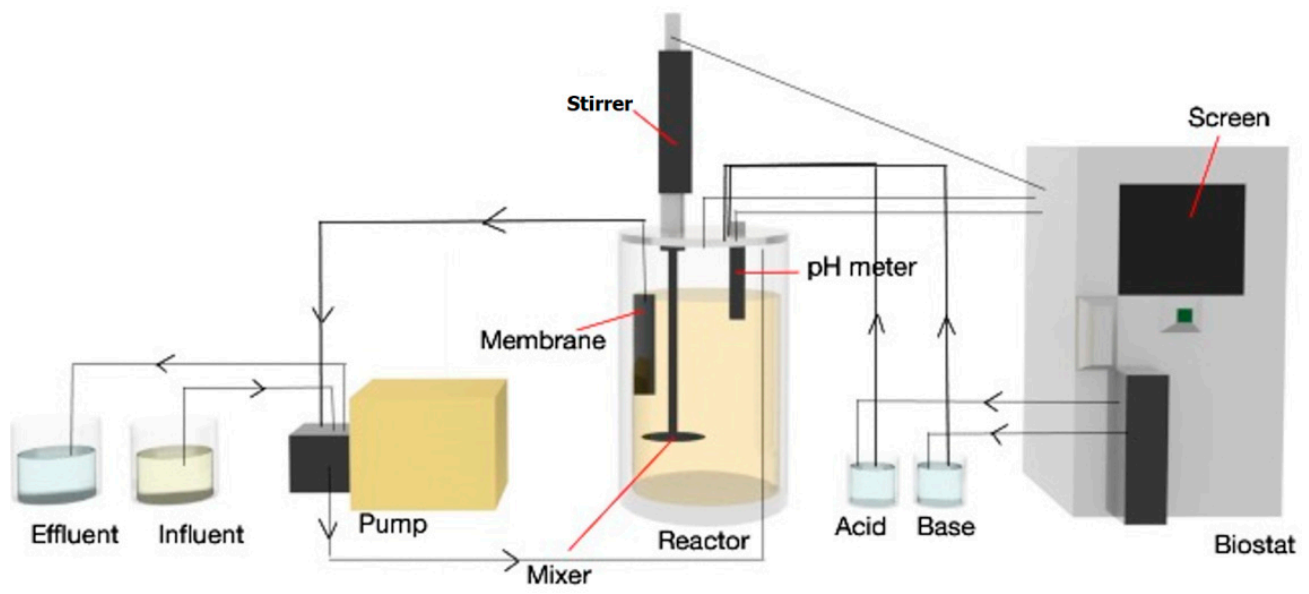

Figure 1. Schematic diagram of the submerged membrane reactor attached to a ench top BIOSTAT system.

\subsection{Data Analysis and Experimental Reproducibility}

The ammonium nitrogen analysis was determined using the Kjeldahl method [14]. The initial reaction velocity $v$ was determined from the equation below.

$$
v=\frac{C_{t}}{\mathrm{t}}
$$


where $C_{t}=$ concentration of $\mathrm{NH}_{4}-\mathrm{N}$ in $\mathrm{mg} / \mathrm{L}$ and $\mathrm{t}=$ time taken for the conversion.

Experiments were performed in duplicate to ascertain the reproducibility of the process. SPSS version 21.0 was used for statistical analysis. One-way ANOVA (with Tukey post hoc test) was used for the analysis of significance in the comparison of multiple experimental results. The student's $t$-test was used to evaluate statistical differences between results.

\subsection{SEM and EDAX Technique}

Scanning electron microscopy (SEM) and energy dispersion X-ray spectroscopy (EDX or EDAX) are chemical microanalysis techniques that are performed together in order to analyze or measure the atomic composition in a membrane before and after use in this study, for proper monitoring of the membrane and to minimize the fouling effect in the membrane used. The membranes used in this study were washed thoroughly with distilled water before being inserted into the reactor. After the system (EMR) was run, the used membranes were removed, weighed with a Mettler analytical balance, and dried at $60{ }^{\circ} \mathrm{C}$ before being takenfor EDAX analysis. The membranes were analyzed by an analyzer of dispersed energy, model EDAX marks Dxprime, with a CDU leap detector. Topographic analysis was also conducted using a JSM-5800LV microscope (JEOL). Morphology images are formed when the primary electron beams interact with the sample secondary electrons, while information on the sample composition isformed as a result of the back-scattering of the electrons. To obtain the elemental composition, we analyzed the topography images as well as the secondary X-rays emitted.

\section{Results and Discussions}

\subsection{Effect of $\mathrm{pH}$ on Enzyme (Urease) Activity}

To study the effect of $\mathrm{pH}$ on urease activity over a range of substrate concentrations, sodium hydroxide $(\mathrm{NaOH})$ and hydrochloric acid $(\mathrm{HCl})$ were used to raise and drop the $\mathrm{pH}$ values. Enzyme activity was evaluated using the Michaelis-Menten equation at different $\mathrm{pH}$ levels $(4.0,6.0,7.0,8.0$, and at no $\mathrm{pH}$ control) and at room temperature $\left(20 \pm 1{ }^{\circ} \mathrm{C}\right)$. The effects of reaction $\mathrm{pH}$ on enzyme (urease) activity at different $\mathrm{pH}$ values are presented in Table 1 below. The results indicate higher enzyme activity at no $\mathrm{pH}$ control, as this has a $\mathrm{K}_{\mathrm{m}}$ value of $223.65 \mathrm{mg} / \mathrm{L}$ and $\mathrm{V}_{\max }$ of 13.83 , which are lower compared to all other $\mathrm{pH}$ values even though the regression coefficient is not the highest. Based on the results shown below, the values of the enzyme kinetic parameters determined from the Lineweaver-Burk plot were selected as the best for urea hydrolysis.

Table 1. Enzyme kinetic values for $\mathrm{K}_{\mathrm{m}}$ and $\mathrm{V}_{\max }$ at different $\mathrm{pH}$ values by using the linearized model.

\begin{tabular}{|c|c|c|c|}
\hline $\mathrm{pH}$ & Kinetic Parameters $\left(\mathrm{K}_{\mathrm{m}}, \mathrm{V}_{\mathrm{max}}\right)$ & $\begin{array}{l}\text { Lineweaver- } \\
\text { Burk }\end{array}$ & Langmuir \\
\hline \multirow[t]{3}{*}{ No control pH } & $\mathrm{mg} / \mathrm{L}$ & 223.65 & 354.15 \\
\hline & $\mathrm{mg} / \mathrm{L} \cdot \min$ & 13.83 & 15.48 \\
\hline & determining coefficient, $\mathrm{R} 2$ & 0.9446 & 0.9973 \\
\hline \multirow[t]{3}{*}{$\mathrm{pH} 4$} & $\mathrm{mg} / \mathrm{L}$ & 334.73 & 724.69 \\
\hline & $\mathrm{mg} / \mathrm{L} \cdot \min$ & 15.77 & 20.2 \\
\hline & determining coefficient, $\mathrm{R} 2$ & 0.9601 & 0.9824 \\
\hline \multirow[t]{3}{*}{ pH 6} & $\mathrm{mg} / \mathrm{L}$ & 353.35 & 675.26 \\
\hline & $\mathrm{mg} / \mathrm{L} \cdot \min$ & 12.37 & 15.8 \\
\hline & Determining coefficient, R2 & 0.8066 & 0.9854 \\
\hline \multirow[t]{3}{*}{ pH 7} & $\mathrm{mg} / \mathrm{L}$ & 418.47 & 525.23 \\
\hline & $\mathrm{mg} / \mathrm{L} \cdot \min$ & 15.1 & 16 \\
\hline & Determining coefficient, R2 & 0.9724 & 0.9873 \\
\hline \multirow[t]{3}{*}{$\mathrm{pH} 8$} & $\mathrm{mg} / \mathrm{L}$ & 630.25 & 1042 \\
\hline & $\mathrm{mg} / \mathrm{L} \cdot \min$ & 15.43 & 16.81 \\
\hline & Determining coefficient, R2 & 0.9084 & 0.9078 \\
\hline
\end{tabular}


The kinetic data were analyzed at different $\mathrm{pH}$ values using the initial rate method. Both $K_{m}$ and $V_{\max }$ values were calculated using linear equations and the results are presented in Table 1 below. From the results obtained, it shows different values of $K_{m}$ and $\mathrm{V}_{\max }$ calculated at no $\mathrm{pH}$ control value to a $\mathrm{pH}$ value of 8 . The $\mathrm{K}_{\mathrm{m}}$ and $\mathrm{V}_{\max }$ values at no $\mathrm{pH}$ control for the Lineweaver-Burk and Langmuir models were calculated to be 223.65 and $354.15 \mathrm{~m} / \mathrm{L}$, and 13.83 and $15.48 \mathrm{mg} / \mathrm{L} / \mathrm{min}$, respectively. The lower the $\mathrm{K}_{\mathrm{m}}$ value, the higher the affinity of enzyme for the substrate and vice versa. Normally, the effect or influence of $\mathrm{pH}$ on activity is usually caused by perturbations of enzyme distributed among differently protonated forms (range 4-9).

A study conducted by Yingjie and Cabral found sharp dependence of both $\mathrm{K}_{\mathrm{m}}$ and $\mathrm{V}_{\max }$ on $\mathrm{pH}$ when analysing urease in a $\mathrm{pH}$ range of 4-9 [14].

\subsection{Effect of Enzyme Concentration on Batch Hydrolysis of Urea}

The lifetime of a membrane used in an enzymatic process is prolonged by the action of the enzyme, and most enzymatic activities take place at lower temperatures and mild $\mathrm{pH}$ ranges. In a study by Munoz-Aguado in1996, it was reported that the use of lower amounts of enzymes in the membrane process can result in lower cleaning efficiency and higher cleaning duration, whereas higher enzymatic concentrations do not necessarily increase the cleaning action, thus increasing membrane fouling $[15,16]$.

In Figure 2, the graph shows that the time taken for urea to hydrolyze in any wastewater containing urea depends on the amount of urease present or added. This also implies that the higher the enzyme urease concentration, the greater the conversion/hydrolysis. For this study, we will be using a urease concentration of $0.067 \mathrm{~g} / \mathrm{L}$.

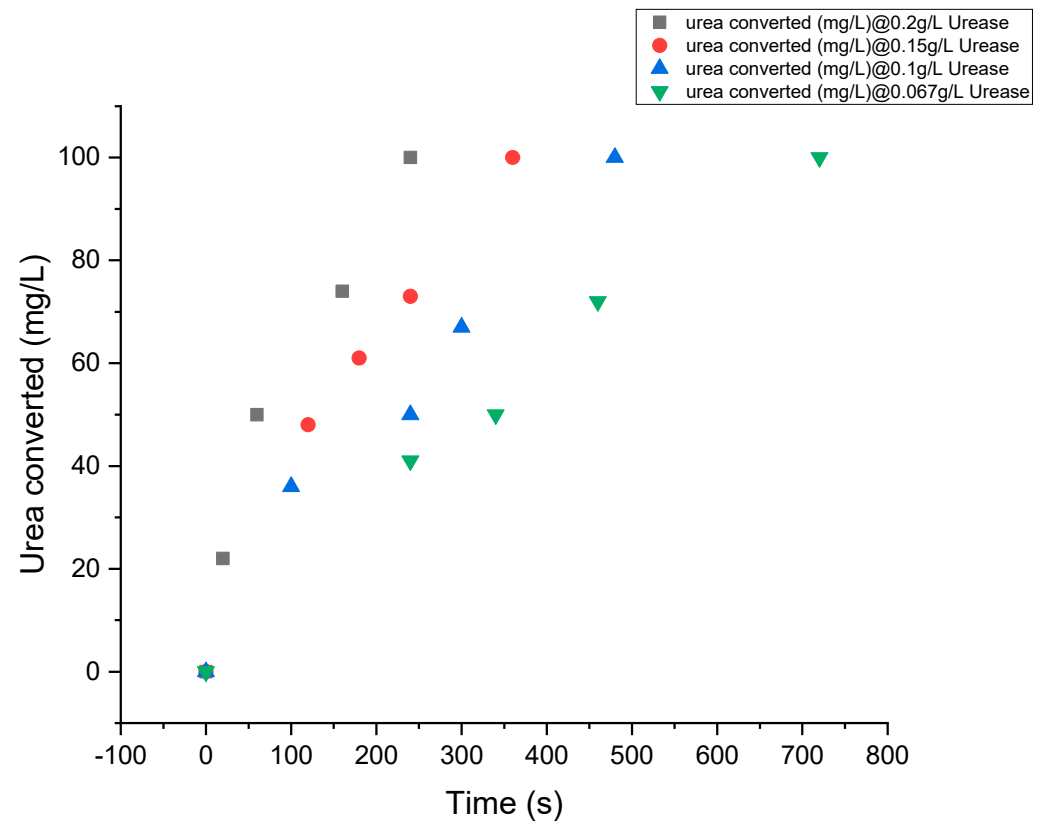

Figure 2. Rate of urea hydrolysis by urease activity.

\subsection{Effect of Feed Concentration on Urease Activity}

The effect of feed concentration on urea activity was studied at $100 \mathrm{mg} / \mathrm{L}$ and $500 \mathrm{mg} / \mathrm{L}$ urea-N concentrations with an enzyme concentration of $0.067 \mathrm{~g} / \mathrm{L}$ and a flow rate of $20 \mathrm{~mL} / \mathrm{min}$. The experiments were performed at room temperature $\left(20 \pm 1^{\circ} \mathrm{C}\right)$ with no $\mathrm{pH}$ control, as the activity of the urease can be affected by both $\mathrm{pH}$ and temperature variations.

According to the graph in Figure 3, for a substrate concentration of $100 \mathrm{mg} / \mathrm{L}$, the ammonia concentration in the permeate increases gradually from an initial value of $33 \mathrm{mg} / \mathrm{L}$ to a maximum conversion value of $100 \mathrm{mg} / \mathrm{L}$ at $22 \mathrm{~h}$. Total conversion of urea to ammonia was achieved after $22 \mathrm{~h}$ and the maximum time taken for the urease activity to elapse was $102 \mathrm{~h}$. For the substrate concentration of $500 \mathrm{mg} / \mathrm{L}$, the urea conversion to ammonia was 
shown to be around $50 \mathrm{mg} / \mathrm{L}$ at $0 \mathrm{~h}$ and reached a peak $(500 \mathrm{mg} / \mathrm{L})$ at around $18 \mathrm{~h}$ and the urease lost all its activity after $74 \mathrm{~h}$. From the results, it can be concluded that the amount of $\mathrm{NH}_{4}-\mathrm{N}$ produced by the system is directly proportional to the initial concentration of the urea in wastewater; however, urease (enzyme) activity was adversely affected by high substrate concentration. These findings are in agreement with research conducted by Bremner, in which hydrolysis rate was affected by high urea concentration due to uncompetitive substrate inhibition or denaturation of enzymes at high urea concentrations [17].

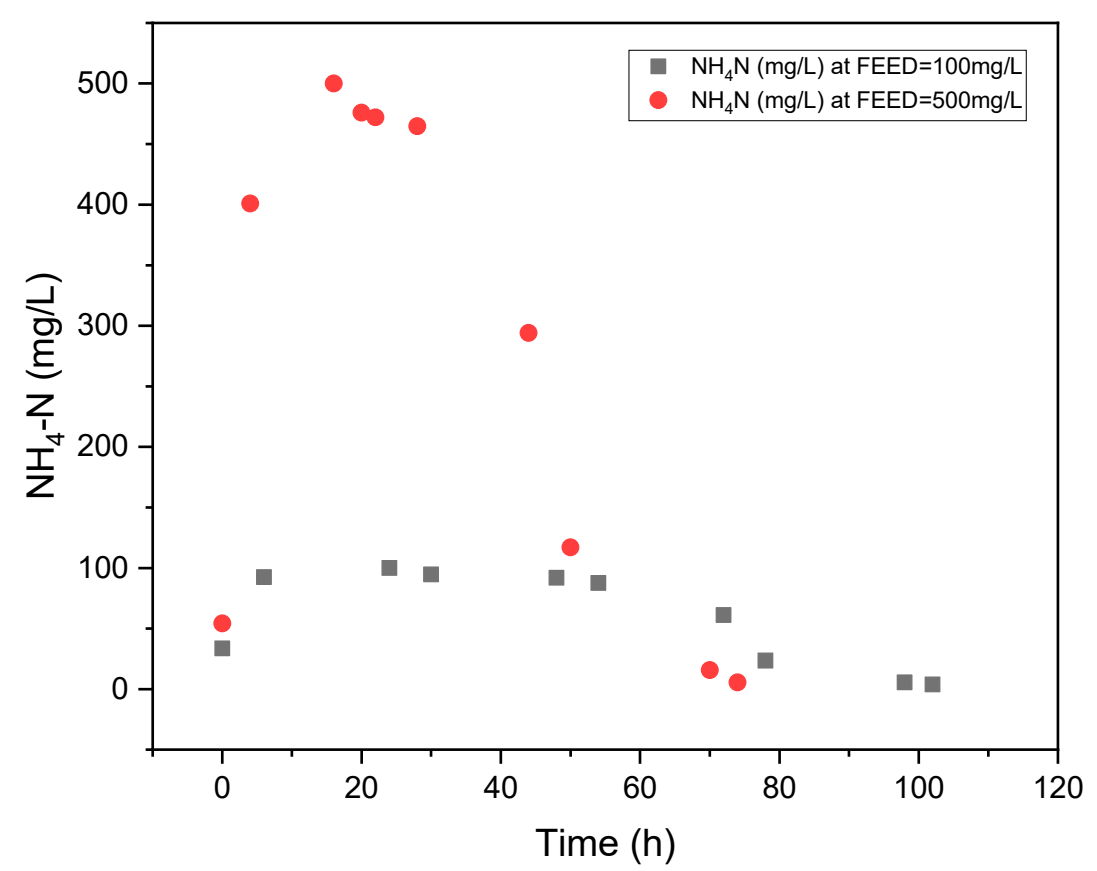

Figure 3. Effect of feed concentration on urease activity in urea conversion.

\subsection{Effect of Ammonium Sulphate $\left(\mathrm{NH}_{4}\right)_{2} \mathrm{SO}_{4}$ Addition on Urease Activity}

In this case, ammonium sulphate $\left(\mathrm{NH}_{4}\right)_{2} \mathrm{SO}_{4}$ was added to the continuous reactor in order to determine its effect on urea hydrolysis. Concentrations of $\left(\mathrm{NH}_{4}\right)_{2} \mathrm{SO}_{4}$ were varied from 0 to $500 \mathrm{mg} / \mathrm{L}$ in a continuous reactor containing urea $(100 \mathrm{mg} / \mathrm{L})$ and urease (concentration of $0.067 \mathrm{~g} / \mathrm{L}$ ) at a stirring speed of $200 \mathrm{rpm}$ and at room temperature $\left(20 \pm 1{ }^{\circ} \mathrm{C}\right)$. The $\mathrm{pH}$ of the substrate was kept the same without being altered and all analyses were performed at room temperature.

As can be seen in Figure 4, urea hydrolysis to ammonia is the best with no addition of $\mathrm{NH}_{4}-\mathrm{N}$, and this is achieved at around $10 \mathrm{~h}$. Moreover, a drastic increase in the time for the urea to hydrolyze occurs as the ammonium nitrogen concentration is reduced, and this in turn increases the urease activity. The enzyme activity is higher with no $\mathrm{NH}_{4}-\mathrm{N}$ addition $0 \mathrm{mg} / \mathrm{L}\left(\mathrm{NH}_{4}\right)_{2} \mathrm{SO}_{4}$ although it takes more time to attain the maximum $100 \mathrm{mg} / \mathrm{L}$ urea hydrolysis $(28 \mathrm{~h})$. The results suggest that urease is inhibited by higher $\left(\mathrm{NH}_{4}\right)_{2} \mathrm{SO}_{4}$ concentrations. This concurs with a research conducted by Deli Tong and Renkou Xu in 2011 [18]. In a similar study by Kumar and Wagenet, urease activity was reported to be lowest in alkaline and saline [19]. This study agrees with a study in which solutions of divalent salts $\mathrm{Na}_{2} \mathrm{SO}_{4}$ and $\left(\mathrm{NH}_{4}\right)_{2} \mathrm{SO}_{4}$ were added to a solution containing enzyme. The efficiency of the formation of the polyelectrolyte-protein complexes was affected by the salt action; at low salt concentrations, the enzyme was drastically activated and it was inhibited at higher salt concentrations [20]. These data can be used to evaluate the optimal working conditions for bioremediation and wastewater treatment either on a pilot-scale or in big plants. 


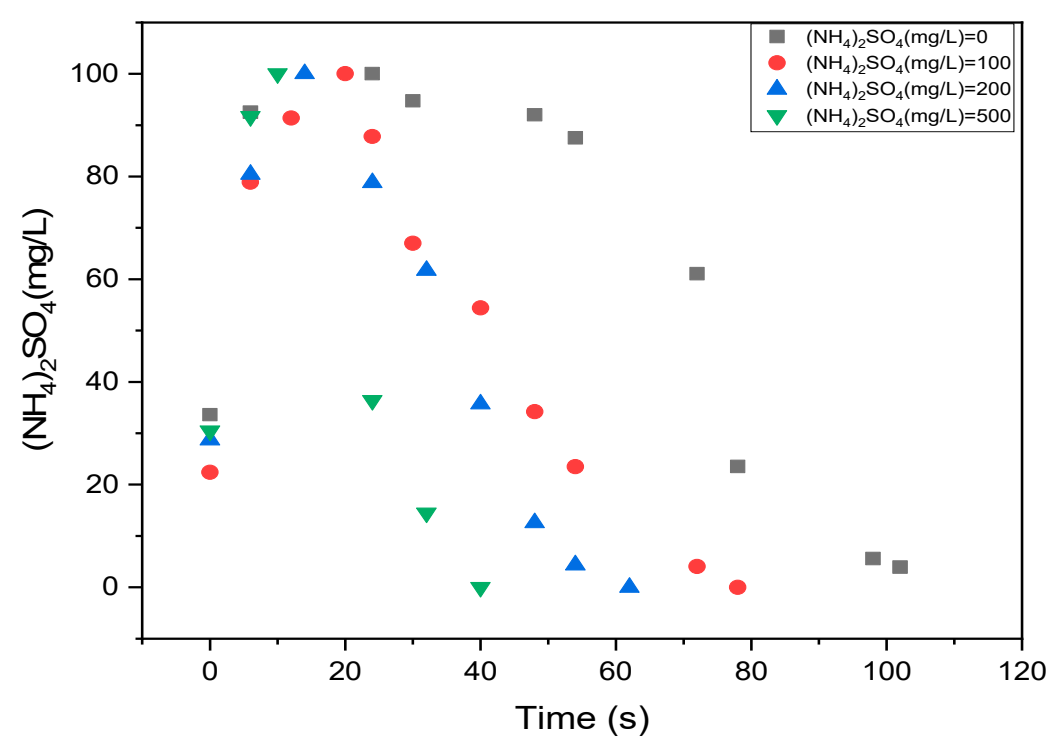

Figure 4. Effect of ammonium-nitrogen addition on urease activity in urea conversion.

\subsection{Effect of Feed Concentration $\mathrm{pH}$ on Urease Activity}

The stability of enzymes is usually affected by the level of $\mathrm{pH}$ of the feed. Most enzyme activities are lost as a result of extremely high or low $\mathrm{pH}$ values. Optimum $\mathrm{pH}$ is achieved where the enzyme activity is the highest (7.0-7.4) as a rapid increase in $\mathrm{pH}$ may have a greater impact on urea hydrolysis [21]. For this study, a continuous system experiment was conducted using a UF membrane, but no $\mathrm{pH}$ adjustment was made as the feed solution $\mathrm{pH}$ was already at the optimum level for urea hydrolysis. The effect of $\mathrm{pH}$ on urease activity was determined in the range of $\mathrm{pH} 4-9$ and at no $\mathrm{pH}$ control in a batch system experiment in this study; Lineweaver and Langmuir plots were used to evaluate the enzyme activity at different $\mathrm{pH}$ values and at room temperature of $20 \pm 1{ }^{\circ} \mathrm{C}$, and the results are presented in Table 1 . The results indicate higher enzyme activity at no $\mathrm{Ph}$ control with $K_{m}=223.65 \mathrm{mg} / \mathrm{L}$ and a $V_{\max }=13.83$, and the lower the $\mathrm{K}_{\mathrm{m}}$ value, the higher the affinity of the enzyme for the substrate and vice versa. The batch system results serve as a reference for the continuous system. A research conducted by [22] shows that only slight differences were observed with a change in $\mathrm{pH}$ in the immobilization of urease. In another research conducted by Nelson and Cox [23], the effect of $\mathrm{pH}$ values results on the variations of enzymatic activity and alteration in charges of the protein and substrates in the reaction were investigated. The optimum $\mathrm{pH}$ for the activity of jack bean urease was reported to be between 7 and 8 [24].

\subsection{Effect of Ionic Strength on Urease Activity}

The ionic strength of a solution is the measure of the concentration of ions and is a key factor to consider in an enzymatic reaction. In this study, the ionic strength effect was also conducted by the addition of sodium chloride $(\mathrm{NaCl})$ to the feed concentration. This was done in different ionic strength concentrations of $\mathrm{I}=0,0.01$, and 0.05. Enzymes can be precipitated or denatured by the action of salts, solvents, and other reagents. Catalytic activity is the key performing parameter of any enzymatic process and depends solely on the concentrations of the substrates and the product, as well as on the $\mathrm{pH}$ and ionic strength [25]. Many studies have reported that an increase in ionic strength reduces enzyme activity [26]. Moreover, the stability and solubility of the enzyme as well as that of the substrate is found to be affected by increased ionic strength. Thus, the effect of salts on stability becomes a more important issue of concern. In a study by Bosco in 2002, the influence of ionic strength on the activity of lignin peroxides showed an Sshaped dependence of the residual activity of lip isoenzyme mixture (LIM) with respect to ionic strength. All these were done to predict the behavior of enzymes with regard to 
ionic strength and to the surrounding environment surrounding the enzyme molecule in general [26].

Figure 5 shows the influence of ionic strength on enzyme (urease) activity for ionic strength values of $I=0,0.01$, and 0.05 . The graph shows a substantial decrease in the activity of urease with an increase in ionic strength over time. The graph also shows how ionic strength serves as an inhibitor in urea hydrolysis. This research agrees with the research conducted by Tikhonenko in 2009 in which the effects of inorganic mono-valent salts of different types were studied. The result shows that the solution of mono-valent salts $\mathrm{NaCl}, \mathrm{KCl}$, and $\mathrm{NH}_{4} \mathrm{Cl}$ decreases the enzyme urease activity drastically with an increase in ionic strength [20].

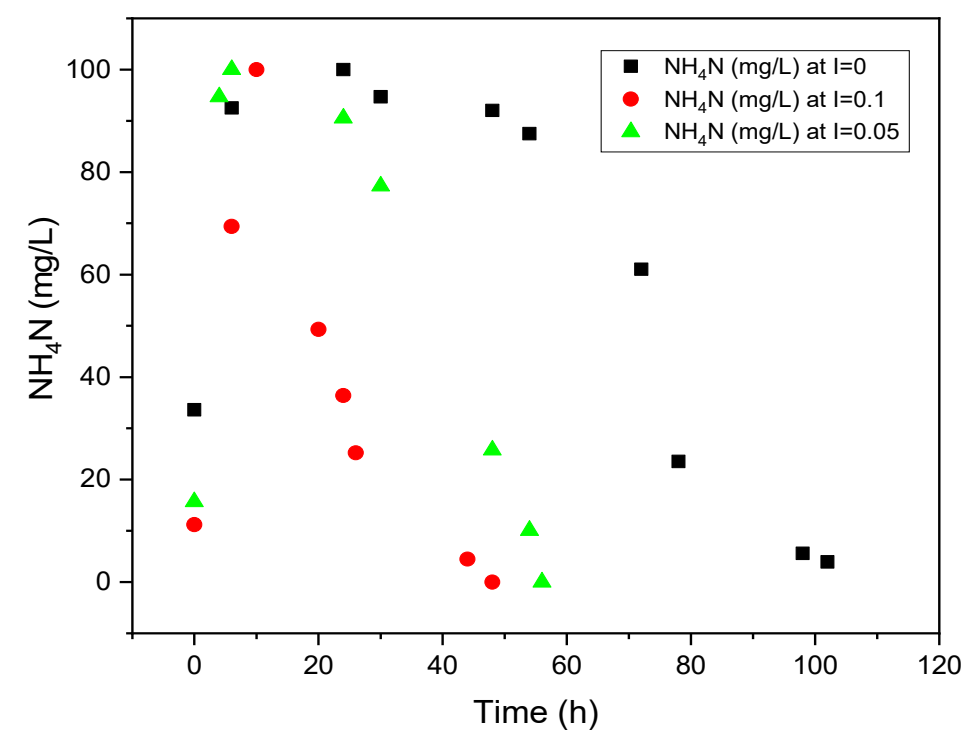

Figure 5. Effect of ionic strength on urease activity in urea conversion.

\subsection{Analysis of Membrane Surface and Fouling}

Membrane autopsy was performed by scanning electron microscopy (SEM) for analysis of membrane morphology. Energy-dispersive X-ray spectroscopy (EDAX) was used to study the physicochemical characteristics of the membrane. The results from the SEM analysis show different elementary compositions at different spots, as shown in Figure 6. The resolution in the images provided can be used to distinguish between a clean membrane and a membrane used in the reactor for easy identification. The EDAX results presented in Tables 2 and 3 below show the elements that are attached or get stacked onto the membrane and the percentage of each element. Whereas Table 4 shows the composition of a clean membrane surface determined by an EDAX technique. For this study, the elements attached to the ultra-filtration membrane being used included a high percentage of oxygen, carbon, calcium fluorine, sodium, and some traces of iron, nickel, and aluminum (Figure 7). The presence of sodium in the membrane was a result of the nature of the manufacturing process, while that of calcium was due to the surface contamination effect. 

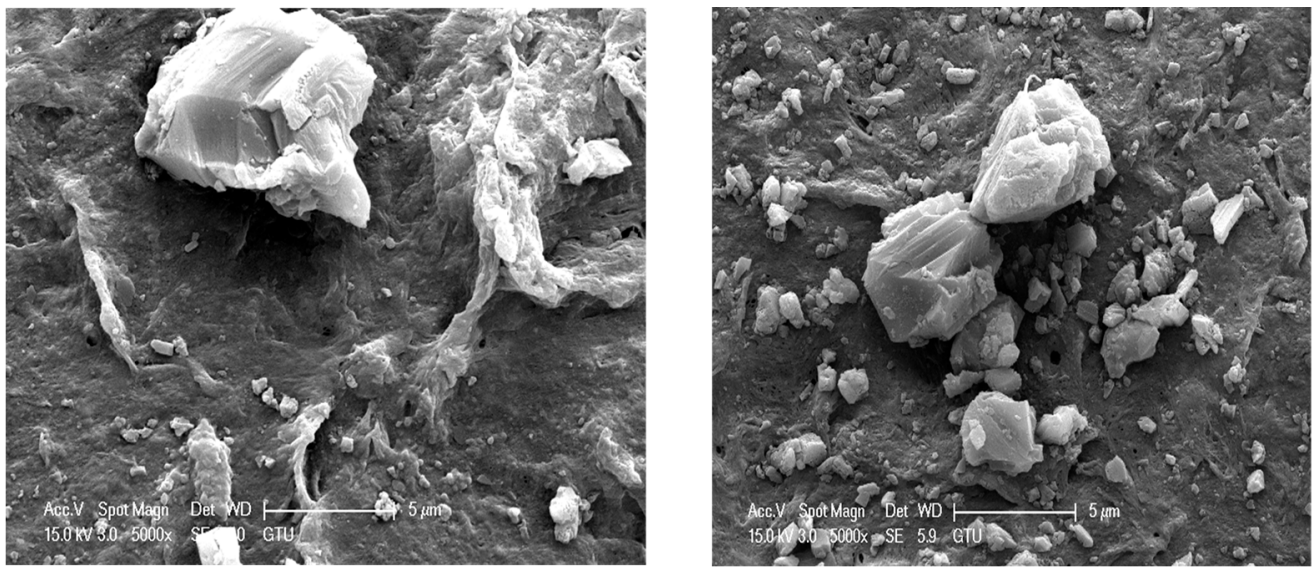

Figure 6. Scanning electron microscopy (SEM) images of the used UF membrane after being used inside the reactor.

Table 2. Elemental composition of the used membrane surface determined by the EDAX technique at different spots.

\begin{tabular}{cccccccc}
\hline Spot 1 & Element & $\begin{array}{c}\text { Conc. } \\
\text { (\%mass) }\end{array}$ & $\begin{array}{c}\text { Net Int. } \\
\text { Error }\end{array}$ & Spot 2 & Element & $\begin{array}{c}\text { Conc. } \\
\text { (\%mass) }\end{array}$ & $\begin{array}{c}\text { Net Int. } \\
\text { Error }\end{array}$ \\
\hline $\mathrm{C}$ & 58.37 & 0.01 & & $\mathrm{C}$ & 18.57 & 0.01 \\
$\mathrm{O}$ & 26.93 & 0.01 & & $\mathrm{O}$ & 42.16 & 0.01 \\
$\mathrm{~F}$ & 3.12 & 0.06 & $\mathrm{~F}$ & 8.48 & 0.01 \\
$\mathrm{Na}$ & 3 & 0.04 & & $\mathrm{Na}$ & 2.78 & 0.02 \\
$\mathrm{Ca}$ & 4.76 & 0.05 & $\mathrm{Mg}$ & 1.48 & 0.03 \\
$\mathrm{Fe}$ & 1.61 & 0.32 & $\mathrm{Al}$ & 0.78 & 0.03 \\
$\mathrm{Ni}$ & 2.21 & 0.21 & $\mathrm{Ca}$ & 25.48 & 0.01 \\
& 100 & - & $\mathrm{Fe}$ & 0.13 & 0.57 \\
& & & $\mathrm{Ni}$ & 0.12 & 0.56 \\
& & & & Total & 100 & - \\
\hline
\end{tabular}

Table 3. Elemental composition of the used membrane surface determined by the EDAX technique.

\begin{tabular}{cccccccc}
\hline Spot 3 & Element & $\begin{array}{c}\text { Conc. } \\
\text { (\%)mass) }\end{array}$ & $\begin{array}{c}\text { Net Int. } \\
\text { Error }\end{array}$ & Spot 4 & Element & $\begin{array}{c}\text { Conc. } \\
\text { (\%mass) }\end{array}$ & $\begin{array}{c}\text { Net Int. } \\
\text { Error }\end{array}$ \\
\hline $\mathrm{C}$ & 13.8 & 0.01 & & $\mathrm{C}$ & 10.96 & 0.01 \\
$\mathrm{O}$ & 40.32 & 0.01 & $\mathrm{O}$ & 46.67 & 0.01 \\
$\mathrm{~F}$ & 7.98 & 0.02 & $\mathrm{Al}$ & 0.79 & 0.02 \\
$\mathrm{Na}$ & 2.9 & 0.03 & $\mathrm{Ca}$ & 41.58 & 0 \\
$\mathrm{Al}$ & 1.18 & 0.02 & & & & \\
$\mathrm{Ca}$ & 33.52 & 0.01 & & & & \\
$\mathrm{Fe}$ & 0.18 & 0.58 & & & & \\
$\mathrm{Ni}$ & 0.13 & 0.58 & & Total & 100 & \\
$\mathrm{Total}$ & 100 & & & & & \\
\end{tabular}

Table 4. Elemental composition of the clean membrane surface determined by the EDAX technique.

\begin{tabular}{cccc}
\hline Spot 3 & Element & Conc. (\%mass) & Net Int. Error \\
\hline $\mathrm{C}$ & 40.32 & 0.01 \\
$\mathrm{O}$ & 6.55 & 0.03 \\
$\mathrm{~F}$ & 48.17 & 0.01 \\
$\mathrm{Al}$ & 1.06 & 0.03 \\
$\mathrm{Ca}$ & 3.67 & 0.06 \\
$\mathrm{Fe}$ & 0.18 & 0.59 \\
$\mathrm{Ni}$ & 0.15 & 0.57 \\
& 100 & \\
\hline
\end{tabular}




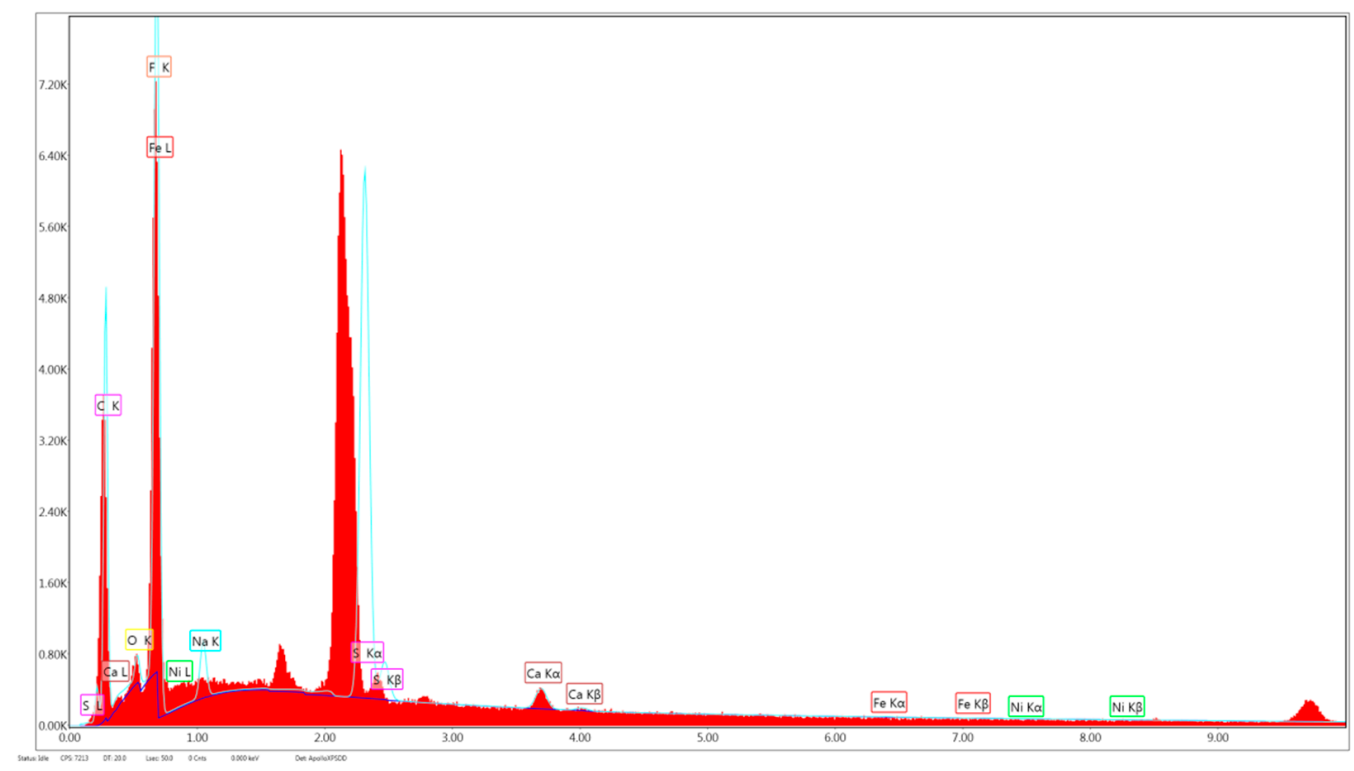

Figure 7. Chemical composition of ultra-filtration membrane determined by the energy dispersive X-ray spectroscopy (EDAX) technique.

\section{Conclusions}

This work presented a concept of an EMR system to achieve ammonia recovery from water containing urea. This EMR system, when put in place, will be used to hydrolyze urea from wastewater and convert itinto ammonia. The system will not only reduce the cost of ammonia recovery, but also reduce the environmental footprint associated with the removal process. From the results obtained, it can be concluded that the system provides an alternative targeting the conversion of urea to ammonia, and also the effect of inhibitors as well as activators in the conversion process. Moreover, another advantage of the proposed system is the continuous use of enzyme in the reactor, which is economical and will be an innovation that will attract stakeholders' attention in wastewater reuse. Furthermore, the costs, energy, and environmental footprint associated with ammonia/ammonium recovery from wastewater are also reduced by this process as less urease is used. The results from this experiment show how the ionic strength effect and ammonium nitrogen addition serve as inhibitors in urea hydrolysis to ammonia and carbon dioxide and also reduce the urease activity. Moreover, the experiment also explored how wastewaters containing higher concentrations of urea can be hydrolyzed to ammonia and carbon dioxide using urease as an enzyme. This was done by varying the feed concentration from 100 to $500 \mathrm{mg} / \mathrm{L}$ as most wastewater containing urea contains approximately $750 \mathrm{mg} / \mathrm{L}$ of urea. However, the results showed that the system could be used in any wastewater treatment system containing urea or ammonia and will be a more economical and sustainable system over a batch process.

Author Contributions: Conceptualization, A.K., D.O. and B.K.; methodology, M.N.Y., B.K.; software, M.N.Y. and P.I.O.; validation, M.N.Y., P.I.O. and A.K.; formal analysis, M.N.Y. and P.I.O.; investigation, M.N.Y.; resources, A.K., B.K.; data curation, M.N.Y. and P.I.O.; writing—original draft preparation, M.N.Y.; writing-review and editing, M.N.Y., H.G. and A.K.; visualization, M.N.Y. and P.I.O.; supervision, H.G. and D.O., A.K. and B.K.; project administration, H.G., D.O., and B.K.; funding acquisition, M.N.Y. All authors have read and agreed to the published version of the manuscript.

Funding: This research received no external fund.

Institutional Review Board Statement: Not applicable.

Informed Consent Statement: Not applicable for this studies as the study is not involving humans and animals. 
Data Availability Statement: Not applicable for this studies not involving humans.

Acknowledgments: The authors would like to thank Gebze Technical University for providing the laboratory where all the experiments were conducted.

Conflicts of Interest: The authors declare that they have no conflict of interest. There are no conflicts of interest regarding this submission.

\section{References}

1. Urbańczyk, E.; Sowa, M.; Simka, W. Urea removal from aqueous solutions-A review. J. Appl. Electrochem. 2016, 46, 1011-1029. [CrossRef]

2. Lilong, Y.; Weiguang, L.; Yuan, R.; Yu, L.; Ying, Z. Study on the way of urea removal by BAF. J. Chem. Soc. Pak. 2013, 35, 1081-1087.

3. Glibert, P.M.; Harrison, J.; Heil, C.; Seitzinger, S. Escalating Worldwide use of Urea-A Global Change Contributing to Coastal Eutrophication. Biogeochemistry 2006, 77, 441-463. [CrossRef]

4. Qin, Y.; Cabral, J.M. Review Properties and Applications of Urease. Biocatal. Biotransform. 2002, 20, 1-14. [CrossRef]

5. Hasanoğlu, A.; Romero, J.; Pérez, B.; Plaza, A. Ammonia removal from wastewater streams through membrane contactors: Experimental and theoretical analysis of operation parameters and configuration. Chem. Eng. J. 2010, 160, 530-537. [CrossRef]

6. Vecino, X.; Reig, M.; Bhushan, B.; Gibert, O.; Valderrama, C.; Cortina, J.L. Liquid fertilizer production by ammonia recovery from treated ammonia-rich regenerated streams using liquid-liquid membrane contactors. Chem. Eng. J. 2019, 360, 890-899. [CrossRef]

7. Kyriakou, V.; Garagounis, I.; Vourros, A.; Vasileiou, E.; Stoukides, M. An Electrochemical Haber-Bosch Process. Joule 2020, 4, 142-158. [CrossRef]

8. Ghimire, U.; Jang, M.; Jung, S.P.; Park, D.; Park, S.J.; Yu, H.; Oh, S.-E. Electrochemical Removal of Ammonium Nitrogen and COD of Domestic Wastewater using Platinum Coated Titanium as an Anode Electrode. Energies 2019, 12, 883. [CrossRef]

9. Simka, W.; Piotrowski, J.; Robak, A.; Nawrat, G. Electrochemical treatment of aqueous solutions containing urea. J. Appl. Electrochem. 2009, 39, 1137-1143. [CrossRef]

10. Guo, J.; Lee, J.-G.; Tan, T.; Yeo, J.; Wong, P.W.; Ghaffour, N.; An, A.K. Enhanced ammonia recovery from wastewater by Nafion membrane with highly porous honeycomb nanostructure and its mechanism in membrane distillation. J. Membr. Sci. 2019, 590, 117265. [CrossRef]

11. Zarebska, A.; Nieto, D.R.; Christensen, K.; Søtoft, L.F.; Norddahl, B. Ammonium Fertilizers Production from Manure: A Critical Review. Crit. Rev. Environ. Sci. Technol. 2014, 45, 1469-1521. [CrossRef]

12. Grimrath, A.; Berends, P.; Rabe, S.; Berger, R.G.; Linke, D. Koji fermentation based on extracellular peptidases of Flammulinavelutipes. Eur. Food Res. Technol. 2011, 232, 415-424. [CrossRef]

13. American Public Health Association. Standard Methods for the Examination of Water and Wastewater, 20th ed.; American Public Health Association-American Water Works Association and Water Environmental Federation: Washington, DC, USA, 1998.

14. Qin, Y.; Cabral, J.M.S. Kinetic studies of the urease-catalyzed hydrolysis of urea in a buffer-free system. Appl. Biochem. Biotechnol. 1994, 49, 217-240. [CrossRef]

15. Muñoz-Aguado, M.; Wiley, D.; Fane, A. Enzymatic and detergent cleaning of a polysulfone ultrafiltration membrane fouled with BSA and whey. J. Membr. Sci. 1996, 117, 175-187. [CrossRef]

16. Shi, X.; Tal, G.; Hankins, N.P.; Gitis, V. Fouling and cleaning of ultrafiltration membranes: A review. J. Water Process. Eng. 2014, 1, 121-138. [CrossRef]

17. Bremner, J.M.; Chai, H.S. Effect of phosphoroamides on ammonia volatilization in soil treated with urea. Biol. SMD Fertil. Soil. 1989, 8, 227-230.

18. Tong, D.; $\mathrm{Xu}, \mathrm{R}$. Effects of urea and $\left(\mathrm{NH}_{4}\right)_{2} \mathrm{SO}_{4}$ on nitrification and acidification of Ultisols from Southern China. J. Environ. Sci. 2012, 24, 682-689. [CrossRef]

19. Thenabadu, M.W.; Dharmakeerthi, R.S. Review urease activity in soils: A review. Nutr. Plant Sri Lanka 1996, 24, 159-195.

20. Tikhonenko, S.A.; Saburova, E.A.; Durdenko, E.N.; Sukhorukov, B.I. Enzyme-polyelectrolyte complex: Salt effects on the reaction of urease with polyallylamine. Russ. J. Phys. Chem. A 2009, 83, 1781-1788. [CrossRef]

21. Engelhardt, S.; Vogel, J.; Duirk, S.E.; Moore, F.B.; Barton, H.A. Assessment of urea hydrolysis as a pretreatment strategy to improve total nitrogen rejection from urine using aquaporin-based membranes in forward osmosis. J. Water Process. Eng. 2020, 34, 101135. [CrossRef]

22. Nicolau, E.; Fonseca, J.J.; Rodriguez-Martinez, J.A.; Richardson, T.-M.J.; Flynn, M.; Griebenow, K.; Cabrera, C.R. Evaluation of a Urea Bioelectrochemical System for Wastewater Treatment Processes. ACS Sustain. Chem. Eng. 2014, 2, 749-754. [CrossRef]

23. Nelson, D.L.; Cox, M.M. Lehninger's Principles of Biochemistry, 4th ed.; W.H. Freeman and Company: New York, NY, USA, 2004.

24. Revilla, M.; Alexander, J.; Glibert, P.M. Oceanography: Methods Urea analysis in coastal waters: Comparison of enzymatic and direct methods. Limnol. Oceanogr. Methods 2005, 3, 290-299. [CrossRef]

25. Bolivar, J.M.; Nidetzky, B. The Microenvironment in Immobilized Enzymes: Methods of Characterization and Its Role in Determining Enzyme Performance. Molecules 2019, 24, 3460. [CrossRef] [PubMed]

26. Bosco, F.; Capolongo, A.; Ruggeri, B. Effect of Temperature, pH, Ionic Strength, and Sodium Nitrate on Activity of LiPs: Implications for Bioremediation. Bioremediat. J. 2002, 6, 65-76. [CrossRef] 